\title{
Leadership and Followership in Organizational Impact Humanity in Government Sector
}

\author{
Norazilawani Ahmad ${ }^{1, *}$, and Hanum $\operatorname{Hassan}^{1}$ \\ ${ }^{1}$ School of Human Development and Technocomunication, Universiti Malaysia Perlis, Perlis, Malaysia
}

\begin{abstract}
Leadership in organizational behavior can be impact of humanity in Goverrment Sector., tourism, service sector. Communication style in the organization is very important and also key forces in providing employees with job satisfaction, humanity and communication skills. When employees do not get satisfaction from their jobs, morale drops an absences and lateness increases. Any person just follow instruction from a leader behavior and subordinates even the step, instruction good job, take action for respontibilities from communication transaction by interpersonal. Even the staff followers support for leaders is enhanced when their decisions affirm a distinct social identity that is shared with followers. Participants showed less support for a leader who favored in group members who were relatively sympathetic to an out group position than for one who favored in group members who opposed an out group position. A social constructionist view is highlighted. I clarify some of the assumptions of this approach, contrasting them with those of a more leader-centered perspective. In an effort to increase the testability of this approach, In outline a general model, paving the way for generating individual and group-level hypotheses, and discuss implications for practice and for future leadership research
\end{abstract}

\section{Introduction}

Literally hundreds of studies have investigated the effects of leader initiating structure and consideration on subordinate satisfaction (Bass, 1999). This research indicates that the subordinates tend to be more satisfied with leaders who exhibit high levels of consideration. The effects of leader initiating structure, on the other hand, are not very consistent, but instead vary as a function of subordinate characteristic like experience, competence and job level and task characteristics like time urgency, physical danger and ambiguity.

The path-goal theory of leadership was developed,in part, to explain the consistent effects of leadership behavior on subordinate satisfaction impact of humanity in Goverrment Sector. Communication style in the organization is very important and also key forces in providing employees with job satisfaction, humanity and communication skills. It is based upon expectancy theory (Vroom, 1998; Porter \& Lawler, 2003) proposes that subordinates will be more satisfied when leader behavior is perceived as:

(1) Increasing personal payoffs for work goal attainment.

(2) Clarifying paths to these goals.

(3) Reducing or eliminating barriers to task completion.

(House \& Dressler, 2000)

One implication of path-goal theory is that situational characteristics determine the relationship between leader behaviour and subordinate satisfaction impact of humanity in Government Sector. Communication style in the organization is very important and also key forces in providing employees with job satisfaction, humanity and communication skills. For example, when the task is routine, subordinates perceive leader initiating structure negatively because it is not needed for goal attainment. In more complex and ambiguous tasks, on the other hand, leader initiating structure is perceived positively because it is critical for task accomplishment (Szilagyi \& Sims, 1990; Vecchio, 1990)

Cranny, Smith, and Stone (1998) estimated that more than 5,000 relevant job satisfaction studies have been published during the twentieth century. Many articles and dissertations credit Hoppock's (1995) study of job satisfaction as pioneering work, but his review of other job satisfaction investigations already included 32 studies. Employees from manufacturing, retailing, and service firms; local, state, and federal government agencies; and schools, colleges, and universities have been participate in job satisfaction research.

\subsection{Significant of the study}

In generally, the study is significance to prove what dimensions of leadership styles will provide satisfaction on the job among staffs of IPK Kedah (Ibu Pejabat Polis Kontinjen Kedah, Jalan Stadium, 05560 Alor Setar, Kedah (STaRT Department), Ibu Pejabat Polis Daerah Kota Setar, Jalan Raja, 05100 Alor Setar, Kedah (Head

\footnotetext{
* Corresponding author: Kbc5183@yahoo.com
} 
Department Start- Financial Section, Store, Communication, Transport ). By having staff satisfaction will bring benefits to the organization as they are able to provide job well and this act will reflect the good image and reputation of the organization itself. It cannot be deny that in every organization, one of the factors that maintain the reputation and good image rely a lot on the services that provide by the staffs.

We hope that the finding of this study will provide valuable information to the organizations to identify areas of leadership styles (initiating structure, consideration) in order to enhance staffs satisfaction impact of humanity in government Sector. Communication style in the organization is very important and also key forces in providing employees with job satisfaction, humanity and communication skills and to provide the quality staffs.

The result of the study may give better understanding of patterns of leadership styles in relation to job satisfaction and indicated the general influences methods of initiating structure style or consideration style and it is much to provide detailed descriptions of individual staff's satisfied. Future research could be conducted on a bigger population including those employees in others government and private sectors employees throughout Malaysia.

IPK Kedah top management is expected to lead according to the standards police department organization and the organization in charge has to uphold the ethical conduct, in both words and actions. At the same time, they need to create a good environment that makes their staffs feel suitable to work with. So, this research tries to find out whether leadership styles give an impact to the staffs job satisfaction.

The procedural problem of this study was to assess the relationships and the effects of leadership styles (initiating structure and consideration) on job satisfaction among the staff in Logistic Department of IPK Kedah.

\subsection{Organization of the study}

This study is structured into five chapters. Chapter one provides an introduction to the topic to be studied, statement of problem, significance of the study, objective of study, research questions, and limitation of study.

Chapter two addresses the (a) meaning of leadership, (b) theoretical approach to leadership, (c) meaning of job satisfaction, (d) theories of job satisfaction, (e) leadership behavior and job satisfaction, (f) job satisfaction as criterion variables, (g) conceptual framework, (h) hypothesis and (i) definition terms.

Chapter three discussed regarding the methodology which includes research population, research sampling, technique of sampling, instrumentation, data collection procedures and data analyses procedures for conducting the study.

Chapter four presents the findings of research include survey responses, description of respondents which is selected accordingly (gender, age, marital status, working experiences and educational level), reliability of the instruments, hypothesis test and summary of hypotheses results. Chapter five summarize the conclusion, along with discussion and recommendation for future research. Lastly conclude reference, and appendix.

\section{Literature Review}

The literature review addressed the (a) meaning of leadership, (b) theoretical approach to leadership, (c) meaning of job satisfaction, (d) theories of job satisfaction, (e) leadership behavior and job satisfaction, (f) job satisfaction as criterion variables, (g) conceptual framework, (h) hypothesis and (i) definition terms.

\subsection{Introduction}

Leadership is one of the fields of organizational that has interest many scholars. Hundreds of books and articles have been published about leadership. Leadership involves a wide range of aspects such as decision making, traits, effectiveness, motivation, and types

However, everyone has opinions and ideas about leadership. These theories are often founded on research and based on people's own experience or popular literature. This chapter therefore sets out to review the literature on leadership behavior, job satisfaction and the relationship between two concepts of leadership behavior styles (initiating structure, consideration) and job satisfaction.

\subsection{Meaning of Leadership}

If scholars could agree on one definition of leadership or perhaps settle on a series of kinds of leadership each with its own reliable, the might, through systematic research, arrive at one comprehensive theory. If they could also agree on definitions o the "good or bad outcomes" of leadership they could also assess how effective various kinds of leadership are in various situations. But there is no general agreement here either. This may be due to the "value" nature of judged leadership effectiveness. Hogan, et al. (2002), insists that leaders must be judged by their result on group life.

What would have obtained without the leader? However, while followers can sometimes function without leaders, $n$ leader is effective without followers to carry out plans and we are left with a puzzle about who should get credit (or blame) for with outcome. Unfortunately, total agreement on these issues is not forthcoming and we must do the consensual definitions of what "good" or "bad" leadership outcomes are.

The source of a leader's influence over his/her subordinates is his/her "position power" and "personal power" (Wexley \& Yulk, 2003). Position power includes the leader's legitimate authority and his/her control over organizational rewards and punishments. Personal power 
is derived from the affection loyalty of subordinates and their respect for the leader's expertise. Position power is primarily determined by the organization, while personal power depends upon the personality and behavior of leader.

Leaders serve as true facilitators and coaches (Gardner, 2005). discussed three roles that leaders, whether they are called team leaders, team coordinators, or coaches, served in team-based organizations. The role of the leader appeared to have shifted from one of formal authority in term of decision making, goal setting, directing floor activity, and troubleshooting to one that focused primarily on coaching and training team members, as well as directing special project, ensuring adequate resources, and monitoring overall performance. According to Bornstein and Smith (2001), leadership is now understood by many to imply collective action, orchestrated in such a way as to bring about significant change while raising the competencies and motivation of all those involved that is action where more than individual influences the process.

\subsubsection{The Trait Approach}

Early research into leadership can be characterized as a search for "the great man". Personal characteristics of leaders were emphasized and the implicit idea was that leaders are born rather than made. All leaders were supposed to have certain stable characteristics that them into leaders. The focus was on identifying and measuring traits that distinguished leaders from non-leaders or effective from ineffective leaders (Hollander \& Offermann, 1998). From these distinctions between leaders and non-leaders, a profile of an "ideal" leader could be derived, which could serve as the basis for selection of future leaders.

Some individual traits that appear to be related to leadership success are high energy level, tolerance for stress, emotional maturity, integrity, and self-confidence. High energy level and stress tolerance help people cope with the hectic pace and demands of most leadership position, the frequent role conflicts, and the pressure to make important decisions without adequate information (Yulk, 1998). Leaders with high emotional maturity and integrity are more likely to maintain cooperative relationships with subordinates, peers, and superiors.

Emotional maturity means that a leader is less selfcentered, has more self-control, has more stable emotion and is less defensive. Integrity refers to a person's behavior being consistent with expressed values and the person being honest and trustworthy. Self-confidence makes a leader more persistent in the pursuit of difficult objectives, despite initial problems and setback. Judge and Bono (2000) reported that the personality factors of extraversion and agreeableness were also associated with success as a leader.

\subsubsection{Charismatic Leadership}

Beginning in the 1970s, a number of leadership theories emerged that focused on importance of a leader's charisma to leader effectiveness. Included within this class of theories is House's theory leadership (1999), Bass's transformational leadership theory (2000), and Conger and Kanungo's (2003) charismatic leadership theory. These theories have much in common. They all focus on attempting to explain how leaders can accomplish extraordinary things against the odds, such as turning around a failing company, founding a successful company, or achieving great military success against incredible adds. The theories also emphasize the importance of leaders' inspiring subordinates' admiration, dedication and unquestioned loyalty through articulating a clear and compelling vision.

A first major application of charisma to the study of formal organizations can be found in House (1999), whose theory combines personal traits, leader behavior and situational factors. According ton house, four personal characteristic of leader contribute to charismatic leadership, dominance, self- confidence, need for influence, and a strong conviction of the integrity of one's own beliefs. Charismatic leaders represent their value and beliefs through role modeling. To create a favorable perception with followers they can engage in image building and express ideological goals (a mission). They communicate high expectations of followers and confidence in followers' ability to live up to expectations.

Bass's (2000), transformational leadership theory identifies four aspects of effective leadership, which include charisma, inspiration, intellectual stimulation and consideration. A leader who exhibits these qualities will inspire subordinates to be high achiever and put the long-term interest of the organization ahead of their own short-term interest, according to the theory.

\subsubsection{Substitutes for Leadership}

Kerr and Kermier (2004) introduced the substitutes for the leadership theory in 1978. The theory's focus is basically concerned with providing an explanation for the lack of stronger empirical support for a relationship between leader traits or leader behaviors and subordinates satisfaction and performance. The substitutes for the leadership theory suggest the characteristic of the organization, the task, and subordinates may substitutes for or negate the effects of leaderships, thus observed relationships between leadership behavior and the importance organizational outcomes.

Substitutes for the leadership make leader behavior such as task-oriented or relationship-oriented unnecessary. Characteristics of the organization that may substitutes for leadership include formalization, group cohesiveness, inflexible ruled and organizational rewards not under the 
control of the leader. Characteristics of the task that may substitute for the leader include ability, experience, training, and job-related knowledge. The substitutes for the leadership theory have generated a considerable amount of interest because it offers an intuitively appealing explanation for why leader behavior impacts subordinates in some situations but not in others. However, some of its theoretical propositions have not been adequately tested. The theory continues to generate empirical research.

\subsection{Meaning of Job Satisfaction impact of humanity in Government Sector}

This is probably one of the most researches and constructs in organizational behavior. Literally thousands of articles have been written about its definition and meaning, its antecedents, and its consequences. Job satisfaction impact of humanity in Goverrment Sector. Communication style in the organization is very important and also key forces in providing employees with job satisfaction, humanity and communication skills may be defined as the emotional state resulting from the appraisal of one's job and as such can be negative, positive, or neural. A basic element in this definition is that job satisfaction impact of humanity in Goverrment Sector. Communication style in the organization is very important and also key forces in providing employees with job satisfaction, humanity and communication skills has to do with an effective state or how one "feels" about one's job in contrast to simply describing a job.

Spector (2001) are present three reasons to clarify the importance of job satisfaction. First, organizations can be directed by humanitarian values. Based on these values they will attempt to treat their employees honorably and with employees are dealt with effectively. High levels of job satisfaction could also be a sign of emotional wellness or mental fitness. Second, organizations can take on a utilitarian in whom position in which employees' behavior would be expected to influence organizational operations according to the employee's degree of job satisfaction impact of humanity in Goverrment Sector. Communication style in the organization is very important and also key forces in providing employees with job satisfaction, humanity and communication skills or dissatisfaction.

\subsection{Theories of Job Satisfaction impact of humanity in Goverrment Sector. Communication style in the organization is very important and also key forces in providing employees with job satisfaction, humanity and communication skills}

\subsubsection{Maslow Needs Hierarchy Theory}

Maslow believed that human beings have five ascending types of "need" which they seek to satisfy or fulfill within different environments (Maslow, 1998). At the bottom of Maslow's "hierarchy" of human need are the basic physiological needs for food, shelter and clothing.
According to the theory, these needs must be "reasonably satisfied" before a person will turn his or her attention to the next higher order need. "Reasonable satisfaction" is culturally defined. One physiological need is met (and there is a certain assurance that will continue to be met), a person turns his or her attention toward the need for the safety from danger.

\subsection{Leadership Behaviour and Job Satisfaction}

Having discussed the major theories of leadership behavior in the first section and of job satisfaction in the second section reviews the empirical evidence on the relationship between leadership behavior and job satisfaction. As what we known primary responsibility to get things done through others (Fruzi \& Patrick, 1998). Effective leader get most of most of their useful information from talking with people (Hill, 1979). In order to communicate with people for information, leader must give sincere effort and commitment. Leader must also work with people for information, leader must give sincere effort and commitment. Good leader must be good coaches who know how to encourage staff to raise their performance at work, improve their knowledge, and realize their full potential (Heller, 1998). Leader must also work with people to solve problems.

"To do this effectively, leader must be able to influence what and how other people do thing" (Hill, 1999). This is a challenge because people are unique and has different personalities, needs goals, desires and background. Each individual's personality is a result from heredity, upbringing, schooling or lack of it, family and friends, work, religion, neighborhoods, and experiences. As a result, managers must always adapt to the employees behavior to take into account the expectations, values, and perceptions of the people they are interacting with (Hill, 1999).

\subsubsection{Gender}

Gender is another employee characteristic which is often to cause variations in reported levels of job satisfaction Sousa-Poza \& Souza-Poza, 2000). There have been many suggested explanations to this phenomenon ranging from genetic differences to an overrepresentation of women with part-time jobs.

Research investigating the relationship between gender and job satisfaction uncovered three possibilities. First, females are more satisfied than males. Second, males are more satisfied than females (Hulin \& Smith, 2001; Locke, Fitzpatrick, \& White, 2000). Third, no difference exists between males and females with respect to job satisfaction (i.e., D'Arcy, Syrotuik, \& Siddique, 2001).

\subsubsection{Age}

The majority of studies on the relationship of age and job satisfaction have found some association between employee age and job satisfaction. Clark et al. (2004) suggest that job satisfaction is U-shaped in age, with higher levels of morale among young workers but that 
this declines after the novelty of employment wears off and boredom with the job sets in. Satisfaction raises again later life as workers become accustomed to their role. In contrast, other studies report a linear positive relationship based on age (Lee and Wilber, 2003). In their study of accountants in Singapore, Ang et al. (2001) report a positive linear relationship between age and job satisfaction (except for one respondent group for which the relationship is curvilinear).

\subsubsection{Marital Status}

The first two employee characteristics dealt with physical off the employees but there have also been reported differences in reported job satisfaction with respect to more mental properties of the employees. Especially educational level has been found to affect the level of job satisfaction and in many job satisfactions has been found to decrease with increasing educational level ,(Robie, et al. 1998, Sousa-Poza \& Sousa-Poza, 2000, Wharton, et al, 2000).

By and large, no differences in the satisfaction scores have been found between married and single employees (Hashim, 1998). However, some studies have found married employees to be more satisfied than unmarried (McDonald \& Gunderson, 2001), and some others have found single employees to be more satisfied than their married counterparts (Wright, et al. 1998).

\subsubsection{Highest Educational Level}

\section{Methodology}

This section will describe the research methodology that was used to test the hypotheses. First we will introduce the study design and discuss the appropriateness and size of the sample. Next, we will describe the actual model to be tested, the data collection process, and then the measure. Finally, we will present the data analysis procedures to establish the measure and test the hypotheses. I am studying in process to defend proposal. All process and step study can be proceed after process defend proposal approval panel and document data. My suggestion will choose as bellow :

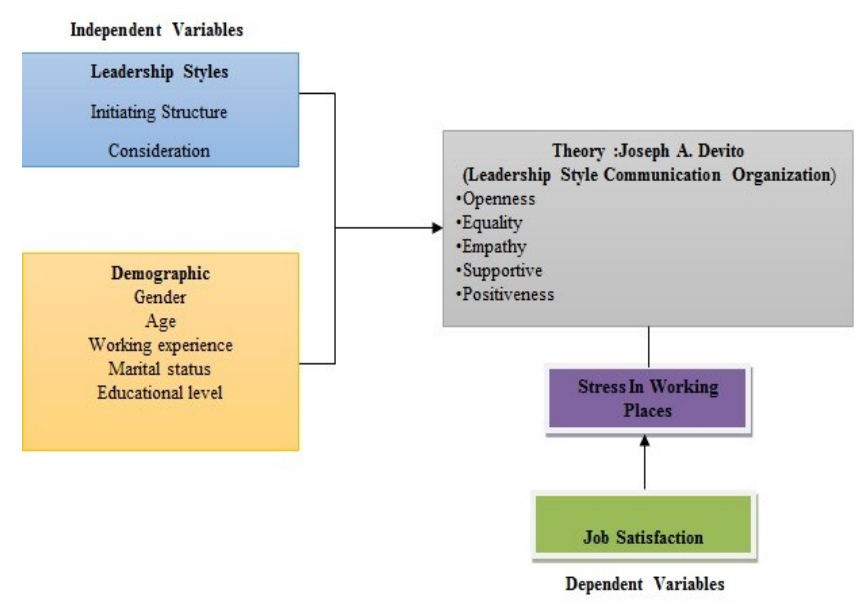

Fig.1. Conceptual Framework

\subsection{Leadership Behaviour and Job Satisfaction 3.1 Instrumentation}

In this study, we used adapted questionnaire for data collection to elicit the opinions of the staffs about leadership styles of their top management towards their job satisfaction.

The questionnaire used in this study consisted of three sections: Section A concerned the demographic factors including gender, age, race, marital status, highest education qualification, previous working experiences, salary, current position and working experiences of the staffs. However item such as race, salary, and current position are not included in hypotheses test. Section B contained of 27 questionnaires on leadership styles and section $\mathrm{C}$ consisted 6 of questionnaires of the job satisfaction. This instruments was selected because it is related with our study and the scale has shown a high level of reliability, good level of validity and high level of consistency.

\section{Findings}

This purpose of this chapter is to present the findings of the analyses of data which were collected in the study of the relationship between leadership styles and job satisfaction of staffs IPK Kedah. The findings of the study are discussed in this chapter based on the research objectives and hypotheses that have been proposed in the Chapter two. The discussions are divided into four main sections. The first section describes the demographic factors of the respondents. Second section indicates the reliability of the variables (leadership styles [initiating structure and consideration] and job satisfaction). The third section describes the general view of job satisfaction and the last part describes the result of the hypotheses test and summary of the results.

\section{Summary of Findings}

This chapter presents the analyses and findings for a whole part of this study. The multiple analyses including descriptive statistics, Pearson correlation, regression analysis, and etc. will gives us the multiple view of interpretations of this study.

\subsection{Summary, Discussion, Conclusions and Recommendations}

This chapter presents the summary, methodology and findings that would be discussed refer to the hypotheses developed for this study. In addition, a brief of conclusion and recommendation of the study for future research are also included.

This study examined the job satisfaction in IPK Kedah. The distribution of demographic factors among the staffs in this organization was analyzed. The relationships and effects between staff's job satisfaction and the independent variables, leadership styles were also determined. 


\section{References}

1. J. Almarri, J. Meewella, T. Mainela, International conference on Excellence in Business. Shariah United Arab Emirates (2012)

2. Saifuddin Abdullah. (2012, 6 Ogos). "Keusahawanan Sosial Basmi Kemiskinan". Akhbar Sinar Harian.

3. Mohamad Mustapha, Keusahawanan Islam (Petaling Jaya, Prentice Hall, 2002)

4. S. Johnson, (2000), "Literature review on social entrepreneurship" available at: www.bus.ualberta.ca/ccse/Publications/Publications/ Lit._Review_SE_November_2000.rtf (accessed February 20, 2011).

5. A. Nicholls, Social Entrepreneurship: New Models of Sustainable Social Change, Oxford University Press, Oxford (2008)

6. J.T. Zietlow, Nonprofit Management and Leadership 13 (1), 85-90 (2002)

7. S.A. Zahra, H.N. Rawhouser, N. Bhawe, D.O. Neubaum, J.C. Hayton, Strategic Entrepreneurship Journal 2 (2), 117-31 (2008).

8. Mohd Adib Abd Muin, Azizi Abu Bakar, Shuhairimi Abdullah, Prosiding: International Conference on Business Innovation, Entrepreneurship and Engineering 2013, 386-399 (2013)

9. Muhammad Ali Hashim, Khalifah Ganti Superman (Kuala Lumpur: Utusan Publications \& Distributors Sdn Bhd., 2013)

10. Mohd Adib Abd Muin, Shuhairimi Abdullah, Muhammad Fakhirin Che Majid, Prosiding: Seminar Penyelidikan Kebangsaan 2014, (2014)

11. Yazilmiwati Yaacob, Ilhaamie Abdul Ghani Azmi, Entrepreneurs' Personality from Islamic Perspective: A Study of Successful Muslim Entrepreneurs in Malaysia, 46(16), (2012)

12. Shuhairimi Abdullah, Aplikasi Nilai- Nilai Murni Dalam Kalangan Usahawan ke Arah Pembangunan Usahawan Muslim Yang Holistik. Kertas Kerja Seminar Keusahawanan Islam II Peringkat Kebangsaan, (2011)

13. Ab. Aziz Yusof, Pengenalan kepada Usahawan dan Keusahawanan (Kuala Lumpur: Scholar Mind Publishing, 2010)

14. Al-Quran al-Karim Terjemahan (Kajang, Selangor, 2012)

15. Shuhairimi Abdullah, Journal of Islamic Human Advanced Research 3, 322-345 (2013)

16. M.A. Abdullah, A. Hoetoro, International Journal of Management and Business Research 1(1), 35-46 (2011)

17. Suhaimi Mhd Sarif, Abdullah Sarwar, Yusof Ismail, Journal of Scientific Research 14 (11): 1463-1470 (2013)
18. Global Entrepreneurship Monitor. (2009). "Report on Social Entreprenurship 2009”. (Report). London. United Kingdom.

19. Saifuddin Abdullah. (2009, 29 Julai). "Keusahawanan Sosial Dalam Penyelidikan". Akhbar Utusan Malaysia.

20. C.S. Teresa, L. N. Patricia Journal of Research in Marketing and Entrepreneurship 11(1), 49-65 (2009)

21. H. Jiao, Social Enterprise Journal 7(2), 130-149 (2011). doi:10.1108/17508611111156600

22. J. Weerawardena, G. S. Mort, Journal of World Business 41(1), 21-35 (2006)

23. P. J. Murphy, S.M. Coombes, Journal of Business Ethics 87, 325-336 (2009)

24. Adnan Alias, Mohamed Dahlan Ibrahim, Keusahawahanan Islam (Petaling Jaya: Prentice Hall, 2002)

25. Radin Siti Aishah, Zaidatol Akmaliah, "Keusahawanan Sosial Dari Perspektif Islam". In Proceeding of the International Conference on Research in Ethics Education 2013. Istanbul Turki (2013)

26. S. Habibollah, A. Hamed. N. Davoud, Journal of Business and Management 5(7), (2010)

27. E. Shaw, (2011). Toward A Theory of Entrepreneurship : The Significance and Meaning of Performance and the Emotion Management of Entrepreneurs A Thesis submitted for the Degree of Doctor of Philosophy By Elizabeth Shaw Brunel School of Business and Management Brunel Unive. Brunel University.

28. J.A. Robinson, J. Mair, K. Hockerts, International Perspectives of Social Entrepreneurship (Palgrave, London, 2009)

29. Mohd. Fadzillah Kamsah, Muhammad Zakaria. Langkah Bijak Usahawan Terbilang (Kuala Lumpur, Telaga Biru Sdn Bhd., 2008)

30. Mohd Adib Abd Muin, Shuhairimi Abdullah, Azizan Bahari, (2014). Model on Social Entrepreneurship: Identify the Research Gap based on Islamic Perspective. International Conference on Social Entrepreneurship 2014, 7-9 Nov 2014, Genting Highland Pahang.

31. J. Marri, J. Meewella, T. Mainela, Social Entrepreneurship and Islamic Philanthropy. International conference on Excellence in Business. (Shariah United Arab Emirates, 2012)

32. Saifuddin Abdullah. (2012, 6 Ogos). "Keusahawanan Sosial Basmi Kemiskinan". Akhbar Sinar Harian.

33. Mohamad Mustapha, Keusahawanan Islam (Petaling Jaya: Prentice Hall, 2002)

34. S. Johnson, (2000), "Literature review on social entrepreneurship", available at: www.bus.ualberta.ca/ccse/Publications/Publications/ Lit._Review_SE_November_2000.rtf (accessed February 20, 2011) 